\title{
KREATIF MEMBANGUN DAERAH MELALUI PEMANFAATAN TEKNOLOGI PADA MASA PANDEMI
}

\author{
Fara Fitriyani \\ Jurusan Akuntansi, Universitas Sultan Ageng Tirtayasa \\ Fara_0606@untirta.ac.id
}

\begin{abstract}
Abstrak
Pemberlakuan Pembatasan Kegiatan Masyarakat (PPKM) Darurat akibat pandemi Covid-19 yang diterapkan oleh pemerintah diharapkan membuat masyarakat tetap produktif dan tetap beraktivitas, khususnya dalam bidang pendidikan, salah satunya adalah kegiatan Pengabdian masyarakat melalui Kuliah Kerja Mahasiswa (KKM) dengan tetap mematuhi ketentuan pemerintah yaitu penerapan protokol kesehatan. Tujuan kegiatan KKM adalah sebagai sarana bagi mahasisiwa untuk mengaplikasikan dan memperluas ilmu pengetahuan dan teknologi melalui model pemberdayaan masyarakat serta memberdayakan masyarakat melalui berbagai aspek pembangunan sebagai upaya mencapai kesejahteraan melalui pemanfaatan teknologi untuk membangun daerah secara kreatif. Kegiatan pengabdian masyarakat melalui KKM ini dilakukan secara online. Hasil pengabdian yang dilakukan diantaranya adalah kegiatan terkait penanganan dan pencegahan covid 19, pendidikan, kewirausahaan, dan lingkungan hidup yang disampaikan melalui pemanfaatan teknologi yaitu youtube dan media sosial sehingga masyarakat dapat mengakses langsung informasi yang disampaikan.
\end{abstract}

Kata Kunci: pemanfaatan teknologi, kreatif, covid-19

\begin{abstract}
The implementation of Emergency Community Activity Restrictions (PPKM) due to the Covid-19 pandemic implemented by the government is expected to keep people productive and active, especially in the field of education, one of which is community service activities through Student Work Lectures (KKM) while still complying with government regulations, namely implementation of health protocols. The purpose of KKM activities is as a means for students to apply and expand science and technology through community empowerment models and empower communities through various aspects of development as an effort to achieve prosperity through the use of technology to develop regions creatively. Community service activities through KKM are carried out online. The results of the service carried out include activities related to the handling and prevention of covid 19, education, entrepreneurship, and the environment delivered through the use of technology, namely YouTube and social media so that the public can directly access the information submitted
\end{abstract}

Keywords: technology utilization, creative, covid-19

\section{PENDAHULUAN}

Pada saat ini selain kondisi kesehatan masyarakat, kondisi lain seperti kondisi ekonomi, kondisi pendidikan, dan kehidupan sosial masyarakat di Indonesia sangat terpengaruh oleh pandemi COVID19. Berdasarkan informasi yang diperoleh dari Badan Nasional Penanggulangan Bencana (BNPB), masyarakat yang terinfeksi COVID-19 di Indonesia berkembang sangat cepat, sehingga Pemberlakuan Pembatasan Kegiatan Masyarakat (PPKM) Darurat diterapkan oleh pemerintah yang berdampak terhadap pembatasan kegiatan masyarakat, diantaranya kegiatan ekonomi, kegiatan pendidikan, dan kegiatan sosial masyarakat lainnya (smeru.or.id). Didalam situasi ini, masyarakat diharapkan tetap produktif 
dan tetap beraktivitas dengan tetap mematuhi ketentuan pemerintah yaitu penerapan protokol kesehatan, salah satunya adalah tetap beraktifitas dalam bidang pendidikan yaitu kegiatan pengabdian masyarakat.

Kegiatan pengabdian yang dilaksanakan melalui kegiatan Kuliah Kerja Mahasiswa (KKM) bertempat di Kelurahan Kotabumi Kecamatan Purwakarta Kota Cilegon Propinsi Banten secara daring (online). Kegiatan ini diharapkan dapat menjadi sarana bagi mahasisiwa untuk mengaplikasikan dan memperluas ilmu pengetahuan dan teknologi melalui model pemberdayaan masyarakat yang dilaksanakan di luar kampus. Kegiatan pengabdian masyarakat ini juga membuktikan adanya hubungan antara dunia pendidikan dengan kehidupan masyarakat. Selain itu, diharapkan pula kepribadian mahasiswa yang peka terhadap berbagai permasalahan yang ada di lingkungan masyarakat dapat terbangun, serta pelaksanakan Tri Dharma Perguruan Tinggi khususnya pengabdian pada masyarakat dapat dikembangkan oleh institusi Pendidikan.

Prinsip co-creation atau kreasi (gagasan) bersama, co-funding atau dukungan bersama, sustainability atau keberlanjutan, fleksibility atau fleksibelitas, dan research based community services merupakan dasar dalam pelaksanaan kegiatan pengabdian masyarakat ini (lldikti, 2019). Permasalahanpermasalahan yang terjadi di masyarakat diharapkan dapat diselesaikan bersama mahasiswa dengan pendekatan partisipasi aktif dan pemberdayaan masyarakat. Selain itu, pengabdian masyarakat ini juga diharapkan dapat membantu dalam perencanaan dan pelaksanaan program pembangunan daerah yaitu dengan membantu masyarakat dalam hal bantuan pikiran dan tenaga, kemampuan masyarakat dalam berfikir, bersikap dan bertindak agar sesuai dengan program pemerintah dalam pembangunan, memperoleh berbagai pemutakhiran informasi yang diperlukan masyarakat dalam pembangunan, serta terjaminnya kelangsungan pembangunan dengan terbentuknya kader-kader pembangunan di masyarakat

\section{METODE PELAKSANAAN}

Pada masa pandemi COVID-19, seluruh kegiatan pengabdian masyarakat melalui KKM dilaksanakan dengan sistem daring (online) bersama dengan 7 (tujuh) mahasiswa yang berasal dari berbagai disiplin ilmu di lingkungan Universitas Sultan Ageng Tirtayasa. Dalam operasionalnya mahasiswa mengembangkan pola pikir dan pola kerja inter disipliner untuk memecahkan permasalahan yang ada di lokasi KKM. Kegiatan secara daring ini dilakukan dengan memanfaatkan youtube dan media sosial lainnya yang ada dengan menyesuaikan keadaan yang dapat dimanfaatkan di ruang lingkup kegiatan yaitu khususnya di Kelurahan Kotabumi, Kecamatan Purwakarta, Kota Cilegon.

Program kegiatan ini direncanakan bertumpu pada permasalahan dan kebutuhan nyata di lapangan, dilaksanakan sesuai dengan daya dukung sumber daya yang tersedia.

Segala bentuk koordinasi dilakukan melalui online dan beberapa kegiatan online yang dilaksanakan adalah acara webinar yang berisikan kegiatan dengan mitra yang dapat dilaksanakan dalam ruang lingkup yang sesuai dengan tema yaitu pembangunan daerah dan pemanfaatan teknologi, serta penyebaran video edukasi.

\section{HASIL DAN PEMBAHASAN}


Tabel 1

Kegiatan Pengabdian Masyarakat

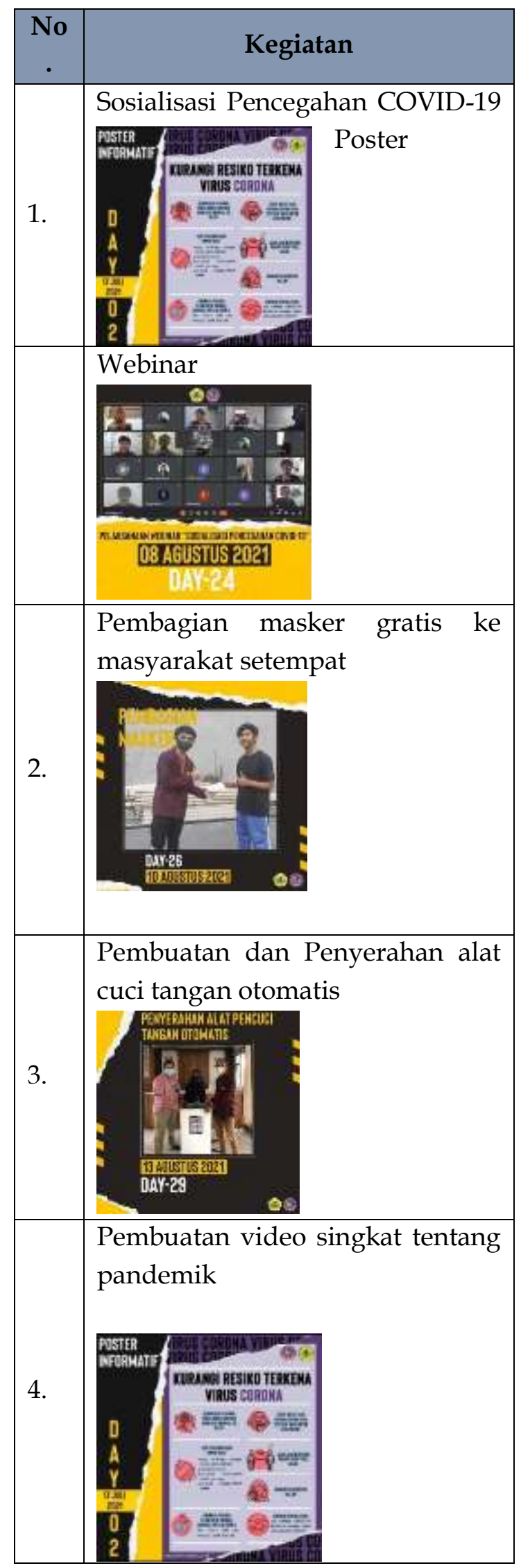

\begin{tabular}{|c|c|}
\hline & https://youtu.be/wuz0I71K6bU \\
\hline 5. & 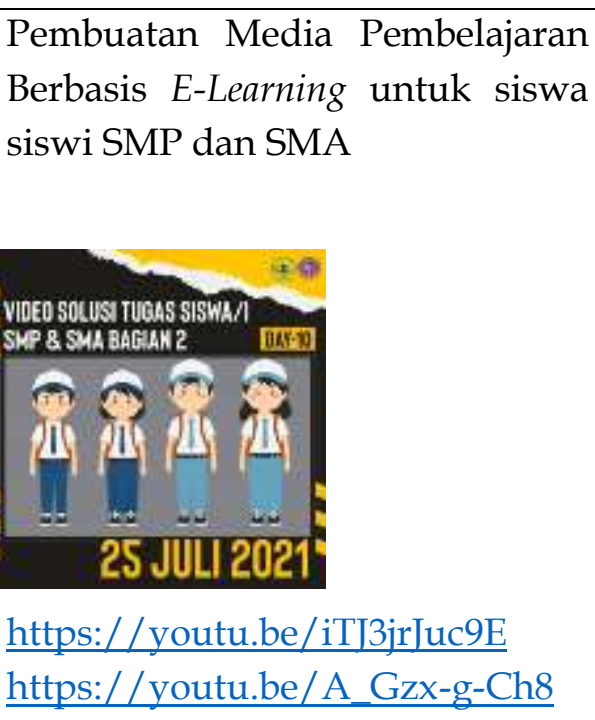 \\
\hline 6. & $\begin{array}{l}\text { Pembuatan kerajinan tangan dari } \\
\text { barang bekas } \\
\text { https://youtu.be/5585UEu5GUo } \\
\text {. }\end{array}$ \\
\hline 7. & 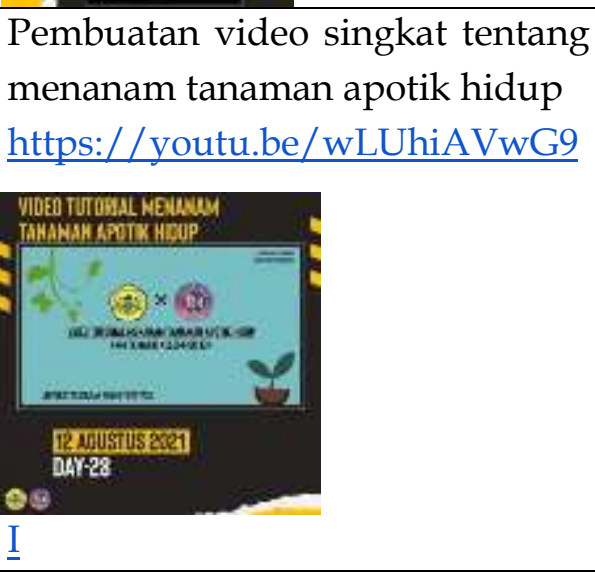 \\
\hline 8. & $\begin{array}{l}\text { Pembuatan video singkat tentang } \\
\text { kegiatan menanam beberapa jenis } \\
\text { tumbuhan }\end{array}$ \\
\hline
\end{tabular}




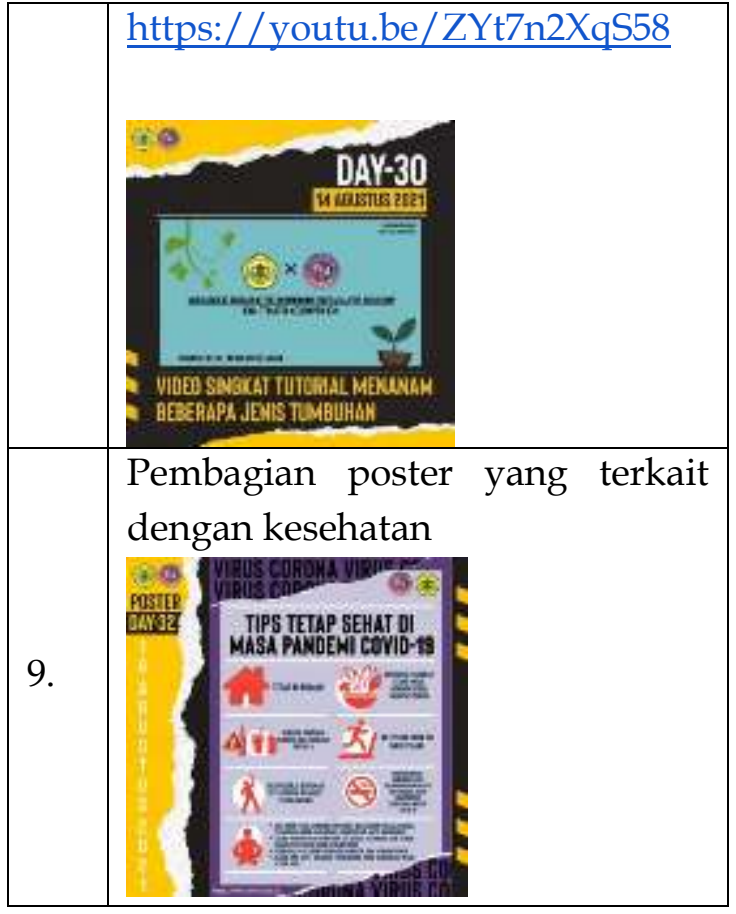

\section{A. Program Utama}

\section{Sosialisasi pengenalan dan pencegahan} COVID-19 melalui poster di Instagram, youtube, dan webinar

Program pertama yang dilakukan dalam kegiatan pengabdian masyarakat ini yaitu sosialisasi Covid-19 melalui poster, video/youtube dan webinar. Sasaran dari kegiatan ini adalah masyarakat Kelurahan Kotabumi khususnya dan seluruh masyarakat pada umumnya. Kegiatan sosialisasi Covid-19 dilaksanakan diantaranya melalui poster tentang cara mengurangi risiko terkena Virus Corona, empat manfaat vaksinasi Covid-19, delapan varian virus Corona hasil mutasi, Etika batuk, serta video dan webinar terkait sosialisai pencegahan Covid-19 dengan narasumber dari praktisi Kesehatan. Hal ini bertujun untuk mengedukasi masyarakat kelurahan Kotabumi khususnya dan seluruh masyarakat pada umumnya. Poster ini ditempelkan di tempat umum di wilayah Kotabumi. Setiap proker di laksanakan dengan mematuhi aturan protokol Covid19. Selain itu, setiap mahasiswa juga melakukan kampanye sosial dengan menshare poster tersebut di akun sosial media. Diharapkan masyarakat umum khususnya pengguna sosial media dapat memperoleh informasi tersebut.

\section{Pembagian masker}

Program utama kedua yaitu membagikan masker kepada masyarakat sekitar Kelurahan Kotabumi. Kegiatan ini adalah bentuk perhatian terhadap masyarakat sekitar Kotabumi, agar dapat hidup adaptif di era normal baru.

\section{Pembuatan dan Penyerahan alat cuci tangan otomatis}

Program utama ketiga adalah pembuatan dan penyerahan alat cuci tangan otomatis. Alat pencuci tangan otomatis ini diharapkan dapat membantu kegiatan mencuci tangan agar praktis dan mudah. Alat cuci tangan otomatis ini dibuat oleh mahasiswa KKM dengan menggunakan alat-alat diantaranya adalah lem tembak, obeng, atrakor, solder, gunting, cutter, dan alat tulis. Bahan-bahan yang digunakan yaitu Arduino uno, gallon, sensor ultrasonic, servo, isi lem tembak, pompa gallon elektrik, tenol, dan lem. Arduino uno dalam alat ini sebagai kontroler sedangkan alat pendeteksi adanya tangan yang akan melakukan cuci tangan yaitu sensor ultrasonik, dan untuk menarik pumping sabun cuci tangan secara otomatis ditarik menggunakan servo.

Proses otomatisasi alat cuci tangan ini yaitu dapat melakukan cuci tangan tanpa menyentuh knop kran. Kran air tidak perlu diputar dan sabun cuci tangan tidak perlu diambil karena cukup dengan menempatkan tangan pada posisi tertentu, maka air dan sabun cair akan otomatis 
keluar. Alat cuci tangan otomatis di tempatkan di kantor kelurahan Kotabumi dan mushola di wilayah Palm Hils.

\section{Pembuatan video singkat tentang pandemi}

Program utama yang keempat dalam pengabdian masyarakat ini adalah pembuatan video tentang pandemi yang diunggah melalui youtube (https://youtu.be/wuz0I71K6bU),

dimana temanya yaitu mengenal vaksin Covid-19. Didalam video ini menjelaskan tentang definisi vaksin, cara kerja vaksin, langkah-langkah pembuatan vaksin, siapa saja yang diperbolehkan dan tidak diperbolehkan memperoleh vaksin. Dengan video ini, diharapkan dapat mengedukasi masyarakat khususnya di Kelurahan Kotabumi, Kecamatan Purwakarta, Kota Cilegon dan masyarakat lain untuk dapat memahami tentang manfaat vaksin dan masyarakat bersedia untuk divaksin sehingga dapat menurunkan angka kasus Covid-19.

\section{B. PROGRAM PENDUKUNG}

\section{Pembuatan Media Pembelajaran Berbasis E-Learning untuk siswa siswi SMP dan SMA}

Program pendukung pertama dalam kegiatan pengabdian masyarakat yaitu pembuatan media pembelajaran berbasis $e$ learning yang diunggah melalui Youtube https://youtu.be/iTJ3jrJuc9E dan https://youtu.be/A_Gzx-g-Ch8.

Sasarannya yaitu pelajar siswa SMP dan SMA di kelurahan Kotabumi dan pengguna sosial media.

Kegiatan ini diharapkan dapat membantu siswa sekolah SMP dan SMA di sekitar kelurahan Kotabumi dan masyarakat umum yang mengalami kendala dalam menyelesaikan tugas-tugas sekolah khususnya mata pelajaran Fisika. Antusiasme siswa sekolah untuk mengikuti pembelajaran berbasis e-learning terlihat dari banyaknya viewers youtube yang diunggah.

\section{Pembuatan kerajinan tangan dari barang bekas}

Program selanjutnya adalah pembuatan wadah aquaponik dengan menggunakan bahan gelas plastik (https://youtu.be/5585UEu5GUo).

Kegiatan ini dilakukan sebagai salah satu cara untuk mengolah limbah plastik yang apabila dibiarkan atau tidak dimanfaatkan akan mencemari lingkungan karena bahan plastik memiliki jangka waktu yang lama untuk terurai di dalam tanah. Sasaran dari program ini adalah masyarakat kelurahan Kotabumi dan masyarakat pada umumnya Aquaponik merupakan sistem pertanian yang mengombinasikan akuakultur dan hidroponik dalam lingkungan yang simbiotik, dalam aquakultur yang normal, proses pembuangan sisa kotoran dari hewan yang dipelihara akan terkumpul di air dan meningkatkan toksisitas air (kemampuan suatu zat yang mengakibatkan ketidaknyamanan) apabila tidak dibuang.

Pembuatan aquaponik merupakan salah satu cara alternatif memelihara ikan dan menanam tanaman dalam satu tempat. Pada proses ini, kotoran dari ikan berupa unsur hara akan dimanfaatkan oleh tanaman sebagai filter vegetasi, dimana apabila kotoran ini dibiarkan di dalam kolam akan menjadi toksik bagi ikan-ikan. Dengan adanya tanaman, zat toksik tersebut menjadi zat yang tidak berbahaya bagi ikan dan suplai oksigen pada air yang akan dimanfaatkan untuk memelihara ikan karena proses filtrasi ini akan menguragi racun yang berasal dari kotoran ikan tersebut. Sehingga siklus ini saling menguntungkan bagi ikan dan tanaman tersebut.

\section{Pembuatan video singkat tentang menanam tanaman apotik hidup}


Program pendukung yang ketiga adalah pembuatan video tentang menanam tanaman apotik hidup (https://youtu.be/wLUhiAVwG9I).

Tanah yang dapat dimanfaatkan untuk ditanami tanaman obat-obatan seperti obat-obatan tradisional disebut tanaman apotik hidup. Obat-obatan tradisional sangat bermanfaat, yaitu untuk mengobati beberapa penyakit dan lebih aman karena sifatnya alami dan memiliki efek samping yang lebih sedikit dibandingkan dengan obat-obatan non alami.

Melalui kegiatan ini diharapkan masyarakat sekitar Kelurahan Kotabumi dan masyarakat umumnya dapat memanfaatkan pekarangan/halaman rumahnya untuk ditanami tanaman yang bermanfaat bagi kesehatan sehingga dapat menjaga Kesehatan selama pandemi ini dan mengurangi mengonsumsi obatobatan non alami.

\section{Pembuatan video singkat tentang kegiatan menanam beberapa jenis tumbuhan}

Program pendukung selanjutnya
adalah membuat video menanam
beberapa jenis
(https://youtu.be/ZYt7n2XqS58).

Kegiatan menanam pada masa pandemi merupakan tren baru sebagai salah satu cara mengurangi rasa bosan pada masa pandemi akibat PPKM. Selain itu, tanaman juga memiliki banyak manfaat, diantaranya sebagai sumber oksigen, sebagai penyejuk, dan lain-lain.

Dikarenakan banyak manfaat yang diperoleh dari kegiatan menanam dan tanaman itu sendiri maka penting bagi kita untuk menanam beberapa jenis tumbuhan di sekitar rumah. Hal inilah yang menjadi alasan pembuatan video kegiatan menanam beberapa jenis tumbuhan ini dibuat.

\section{Pembagian poster yang terkait dengan Kesehatan}

Saat ini, banyak masyarakat yang terpapar virus corona dengan berbagai varian baru. Hal ini dapat diakibatkan imunitas tubuh yang menurun, yang disebabkan oleh pola hidup, seperti pola makan dan pola tidur yang tidak teratur. Melalui poster-poster kesehatan ini diharapkan dapat membantu masyarakat Kelurahan Kotabumi dan sekitarnya untuk saling mengingatkan akan bahaya virus corona dan masyarakat dapat terhindar dari terpapar virus tersebut.

\section{KESIMPULAN DAN SARAN Kesimpulan}

1. Mahasiswa menjadikan kegiatan pengabdian masyarakat sebagai sarana untuk mengaplikasikan dan memperluas ilmu pengetahuan dan teknologi melalui model pemberdayaan masyarakat yang dilaksanakan di luar kampus dan ilmu yang dimiliki mahasiswa dapat diserap oleh masyarakat dalam meningkatkan wawasan yang kemudian dapat menerapkannya dalam kehidupan sehari-hari

2. Mahasiswa melalui kegiatan pengabdian masyarakat dapat berperan aktif dalam kehidupan masyarakat antara lain mahasiswa beradaptasi dengan kehidupan masyarakat, belajar bagaimana bersosialisasi kepada masyarakat, memahami budaya dan karakter serta adat istiadat masyarakat setempat.

3. Mahasiswa turut serta berperan aktif membangun masyarakat melalui pemanfaatan teknologi dengan berupaya membantu mengatasi 
permasalahan yang timbul di tengah masyarakat

4. Para pelajar yang mengalami kesulitan atau mungkin ketinggalan pelajaran akibat pandemic Covid 19 dapat terbantu melalui pembelajaran berbasis e-learning.

\section{Saran}

1. Program pengabdian masyarakat diharapkan dapat diteruskan ke masyarakat lain guna membantu dalam pembangunan daerah melalui pemanfaatan teknologi pada masa pandemi

2. Masyarakat diharapkan tetap menjaga kebersihan salah satunya dengan selalu rajin cuci tangan dan memakai masker untuk menjaga Kesehatan tubuh dari pandemi Covid 19

\section{DAFTAR REFERENSI}

Lembaga Layanan Pendidikan Tinggi Subdit Pemberdayaan Masyarakat Direktorat Riset dan Pengabdian
Kepada Masyarakat. (2019). Pengabdian Kepada Masyarakat.

Marfai, Aris. (2020). Program Pengabdian dan KKM untuk Mendukung New Normal Pasca COVID-19. Universitas Gadjah Mada, 2020

Pedoman KKM Online. (2021). Universitas Sultan Ageng Tirtayasa

Smeru.or.id. (2021). Studi Dampak SosialEkonomi Pandemi COVID-19 di Indonesia.

Wijaya, Hendra, dkk. (2020). Gerakan Produktif dan Hidup Sehat Dalam Mengahadapi Pandemi Covid 19 di Desa Dajan Peken Tabanan

https://youtu.be/wuz0I71K6bU https://youtu.be/iTJ3jrJuc9E https://youtu.be/A_Gzx-g-Ch8 https://youtu.be/5585UEu5GUo https://youtu.be/wLUhiAVwG9I https://youtu.be/ZYt7n2XqS58 